\title{
Gradations of Degradation: Ezekiel's Underworld as a Temple of Doom
}

\author{
Sara Wells and Christopher B. Hays (Fuller Theological \\ SEMINARY)
}

\begin{abstract}
Ezekiel's underworld is characterised by hierarchy and gradation. Insofar as that is also true of sacred spaces in the Bible, Ezekiel's underworld can also be imagined, heuristically, as a kind of unholy temple. Each of the three primary descriptions of holy space in the Hebrew Bible (the Priestly tabernacle, Solomon's temple, and Ezekiel's temple) has three primary graded spaces (inner sanctum, outer sanctum, and court). Ezekiel's underworld has three primary graded spaces: Sheol, the Pit, and the extremities of the Pit. In each case, the farther one moves in from the entrance, the more unholy the space. Like the tabernacle and temples, Ezekiel's underworld also has further gradations within the primary space, and these finer gradations of unholiness are marked by factors such as the length of the passage dedicated to a nation and the presence of associates in the nation's sphere of influence.
\end{abstract}

KEYWORDS: Ezekiel, Underworld, Temple and Tabernacle, Priestly literature, Mesopotamian literature, Gradations of holiness

\section{A INTRODUCTION}

Hierarchical structures and gradations of holiness have long been recognised as fundamental to the book of Ezekiel. ${ }^{1}$ In the case of Ezekiel's temple, Stephen Cook and Corrine Patton traced six or seven graded areas in the complex. ${ }^{2}$

* Submitted: 14/10/2020; peer-reviewed: 20/11/2020; accepted: 26/11/2020. Sara Wells and Christopher B. Hays, "Gradations of Degradation: Ezekiel's Underworld as a Temple of Doom," Old Testament Essays 33 no. 3 (2020): 490-514. DOI: https://doi.org/10.17159/2312-3621/2020/v33n3a8.

The authors are grateful to participants of the Theological Perspectives on the Book of Ezekiel section of the Society of Biblical Literature for their stimulating dialogue on this paper, and to the anonymous reviewers at OTE for their helpful suggestions. Christopher B. Hays is a research associate of the University of Pretoria, South Africa. 1 For example, see Stephen L. Cook and Corrine Patton, eds., Ezekiel's Hierarchical World: Wrestling with a Tiered Reality (eds. Stephen L. Cook and Corrine L. Patton; Society of Biblical Literature Symposium Series 31; Atlanta: SBL, 2004).

2 Stephen L. Cook and Corrine Patton, "Introduction: Hierarchical Thinking and Theology in Ezekiel's Book," in Ezekiel's Hierarchical World: Wrestling with a Tiered Reality (eds. Stephen L. Cook and Corrine L. Patton; Society of Biblical Literature 
Wells \& Hays, "Degradation," OTE 33/3 (2020): 490-514 491

Factors that go into their analysis and those of other scholars include the horizontal and vertical ordering of the temple as well as the employment of steps, narrowing entrances, and gatehouses to mark boundaries. Cook and Patton rightly perceive that "a variety of evidence requires us to reckon with unusually hierarchical dimensions in Ezekiel's thinking and theology compared with other biblical texts and traditions."3

Ezekiel has one of the most extensive and complex descriptions of the underworld in the Bible, and various scholars have suggestively hinted that the underworld's structure in the book could be analysed from a hierarchical perspective as well, but this has yet to be carried out in any detail. ${ }^{4}$ In light of comparative data from neighbouring religions and a new literary analysis, the present article shows that, in Ezekiel 32, the underworld has a hierarchy consistent with the book's other orderly structures.

Ezekiel's underworld can be understood as a negative mirror image of the holy spaces in the Hebrew Bible - as a kind of unholy temple. Like the tabernacle and temples, it has three primary graded spaces - Sheol, the Pit, and the "extremities of the Pit." The farther one moves away from the centre, the more unholy the space. Like sacred spaces, Ezekiel's underworld also has finer gradations within the primary space, so that the nations in the underworld, in effect, are ranked. These gradations also require some literary sensitivity to identify - they depend on factors such as the nation's power, the length of the passage dedicated to it, and the presence or absence of associates in the nation's sphere of influence.

Ezekiel 32 also repeatedly emphasises that one aspect of these nations' degradation is burial with the uncircumcised. "Uncircumcision" characterises all parts of the underworld and associates its inhabitants with impurity. Although

Symposium Series 31; Atlanta: SBL, 2004), 13-14. See also Saul M. Olyan, Rites and Rank: Hierarchy in Biblical Representations of Cult (Princeton: Princeton University Press, 2000), 19-25.

3 Cook and Patton, "Introduction," 14.

4 Boadt hinted some decades ago that Ezekiel's hell was stratified (Lawrence Boadt, Ezekiel's Oracles against Egypt: A Literary and Philological Study of Ezekiel 29-32 [BibOr 37; Rome: Biblical Institute Press, 1980], 154-161). Brian Doak, who offers the most detailed analysis, modestly describes his own summary as "crude" ("Ezekiel's Topography of the (Un-)heroic Dead in Ezekiel 32:17-32," JBL 132 [2013]: 620). See also Dale Launderville, Spirit and Reason: The Embodied Character of Ezekiel's Symbolic Thinking (Waco: Baylor University Press, 2007), 309-312; Safwat Marzouk, Egypt as a Monster in the Book of Ezekiel, (FAT/II 76; Tübingen: Mohr Siebeck, 2015), 221-225. 
the whole of the underworld Pit is "unholy," there are gradations within it, just as the whole temple is holy and there are gradations within it.

\section{B THE TIERED MESOPOTAMIAN UNDERWORLD}

The Hebrew Bible generally offers little explicit information about the structure of the underworld, but it would be surprising if it offers no hint of the rich and diverse speculation about the netherworld that was present in other ancient Near Eastern cultures. Since Ezekiel is set in Babylon, and many Mesopotamian influences on the book have been identified, ${ }^{5}$ some consideration of the Mesopotamian underworld may helpfully set the stage for Ezekiel's.

Different locations can be perceived within the Mesopotamian underworld. The dead were envisioned as traveling from the grave to the netherworld where they would live. Certain features of this image should be noted. First, the entrance to the underworld is a gated palace usually called (in Sumerian) Ganzer. ${ }^{6}$ Beyond Ganzer lived the dead, restrained by its gates from overrunning the living. Certain names for the underworld (e.g., erșétu rabìtu or erșetu rapaštu) indicate that it was envisioned as being large, and it appears to have had a "bottom" (Sum. dúr.kur.ra). ${ }^{7}$

Three particular Mesopotamian texts merit mention, since they indicate more refined ranks within the underworld. First, in Gilgamesh XII, the deceased Enkidu famously returns from the netherworld to give Gilgamesh a report; those in the underworld, he says, fare very differently depending on the number of sons they have (and thus the quality of care they receive). Those with seven sons are enthroned like demigods, while those with none grovel like beggars in the gutter. ${ }^{8}$ Second, in the Descent of Inanna/Ishtar, the eponymous goddess passes

5 For comment on the prophet's literacy and likely familiarity with Babylonian literary traditions, see Michael C. Astour, "Ezekiel's Prophecy of Gog and the Cuthean Legend of Naram-Sin," JBL 95 (1976): 579; S. P. Garfinkel, "Studies in Akkadian Influences in the Book of Ezekiel" (PhD diss., Columbia, 1983); Daniel Bodi, The Book of Ezekiel and the Poem of Erra (Freiburg, Schweiz; Göttingen: Universitätsverlag; Vandenhoeck \& Ruprecht, 1991), 35-51, 314-315; John Kutsko, Between Heaven and Earth (Winona Lake: Eisenbrauns, 2000), 15-23; B. N. Peterson, Ezekiel in Context (PTMS 182; Eugene: Pickwick Publications, 2012), 18-23; D. S. Vanderhooft, "Ezekiel in and on Babylon" in Bible et Proche-Orient, Mélanges André Lemaire III (Transeuphratène 46; Paris: Gabalda, 2014): 99-119.

6 Wayne Horowitz, Mesopotamian Cosmic Geography (MC 8; Winona Lake: Eisenbrauns, 1998), 358-359; Dina Katz, The Image of the Netherworld in the Sumerian Sources (Bethesda: CDL Press, 2003), 45-46, 85-91.

7 Katz, The Image of the Netherworld, 29-30.

8 A. R. George, The Babylonian Gilgamesh Epic: Introduction, Critical Edition, and Cuneiform Texts (2 vols.; Oxford: Oxford University Press, 2003), 734-735. 
through seven gates in the city of the underworld, strongly suggesting that the authors envisioned it comprising different areas or levels. ${ }^{9}$ The same structure of seven gates is found in Nergal and Ereshkigal (11. 194-201). Lastly, in the Netherworld Vision of an Assyrian Prince, the prince is taken on a tour of hell in which he is shown the netherworld's terrifying denizens, which include the king and queen of the underworld and their entire court and entourage..$^{10}$ Thus, the underworld had its own social hierarchy, mirroring human societies. This is not to say that one can systematise a single view of the underworld in Mesopotamian thought; in general, it features gradation and rank.

Ezekiel's tour of hell is unique in the Hebrew Bible, but there are other indications that complex images of the underworld had currency. ${ }^{11}$ The underworld is occasionally portrayed in common Mesopotamian manner as a gated city (Job 38:17; Ps 9:13), and Ezek 31:15 refers to the "rivers (נהרות) of Sheol," a feature widely attested of the Mesopotamian underworld. ${ }^{12}$ The royal dead are imagined enthroned (Isa 14:9), which implies social stratification; and death and its agents are deified in many cases. For example, Sheol swallows (Isa 5:14); Death/Mot is insatiable (Hab 2:5); death is strong (Song 8:6); death is a shepherd (Ps 49:14) and a source of plagues (Hos 13:14). Death is a murderous demon that creeps through windows (Jer 9:20); other unspecified demons stalk in darkness (Ps 91:6) and terrorise suffering people (Pss 55:5; 88:16); and among the demonic forces seem to be Rešeph (Hab 3:5; Ps 78:48-49). ${ }^{13}$ Taken together, these texts (and others) suggest awareness of a developed mythology about the underworld and its powers. The underworld and afterlife were much more

9 Pirjo Lapinkivi, The Neo-Assyrian Myth of Ištar's Descent and Resurrection (Helsinki: Neo-Assyrian Text Corpus Project, 2010), 79-81. Since there was no ancient Mesopotamian city with seven walls (three was the maximum), Lapinkivi suggests that the seven walls correspond to the seven layers of a ziggurat.

10 Wolfram von Soden, "Die Unterweltsvision eines assyrischen Kronprinzen," ZA 43 (1936): 1-31; Alasdair Livingstone, "The Underworld Vision of an Assyrian Prince," in Court Poetry and Literary Miscellanea (SAA 3; Helsinki: Helsinki University Press, 1989), 68-76.

11 One of the foundational works is Martha Himmelfarb, Tours of Hell: An Apocalyptic Form in Jewish and Christian Literature (Philadelphia: University of Pennsylvania, 1983). The category is widened and the literature updated by Seth L. Sanders, "The First Tour of Hell: From Neo-Assyrian Propaganda to Early Jewish Revelation," JANER 11 (2009): 151-169.

12 Horowitz, Mesopotamian Cosmic Geography, 355-358.

13 Christopher B. Hays, Death in the Iron Age II and in First Isaiah (FAT 79; Tübingen: Mohr Siebeck, 2011), 179-184. 
complicated in ancient Israelite and Judean thought than has often been recognised.

The focus here is on the Masoretic Text, which has the fullest version of Ezek 32. The Septuagint, represented by Vaticanus ("B") is shorter than MT and Papyrus 967 is shorter still. ${ }^{14}$ Some of the features this analysis focuses on are absent from one or both Greek texts. Significantly for our analysis, the MT includes an Elam "doublet" in vv. 24-25 which is not original (see below). Although the MT is sometimes judged as being later than the Greek, the interpretation of past warriors (גבורים) as "giants" in the Greek versions is more consonant with later Hellenistic reflection such as 1 Enoch and the Book of Giants. Therefore, the priority of the variant texts is not well agreed upon. ${ }^{15}$ These text-critical assessments underlie the analysis but textual criticism is not the primary interest here. ${ }^{16}$

\section{HOLINESS AND GRADATION IN PRIESTLY LITERATURE}

Broadly, priestly literature depicts gradations of holiness in terms of concentric circles, with the inner sanctum of the tabernacle/temple as the holiest place, moving outward to the outer sanctum and courtyard with diminishing grades. ${ }^{17}$

"Priestly literature" in the Bible is of course not of a single piece. There is a basic distinction between an original Priestly $(\mathrm{P})$ and a later Holiness

14 For a thorough treatment of the subject, see Ingrid E. Lilly, Two Books of Ezekiel: Papyrus 967 and the Masoretic Text as Variant Literary Editions (VTSup 150; Leiden: Brill, 2012).

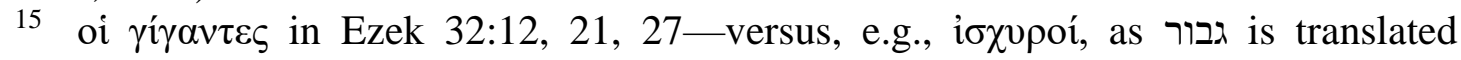
elsewhere in the LXX. Richard J. Bauckham detects a connection between the Watchers and Titans in LXX Ezek 32:27, implying a Hellenistic context for the adaptation of Ezekiel's text. He points out that the Watchers were sometimes compared with the Titans, e.g., by Josephus, Ant 1.73. See Bauckham, Jude, 2 Peter (WBC 50; Dallas: Word, 1983), 249. Note also that Block argues that p. 967 was secondarily reordered to conform to apocalyptic ideals characteristic of the late intertestamental period (Daniel I. Block, The Book of Ezekiel: Chapters 25-48, vol. 2, NICOT 26 [Grand Rapids: Eerdmans, 1998], 337-342).

16 See, for example, the more integrated reading of Moshe Greenberg, Ezekiel 21-37 (New York: Doubleday, 1997), 668. Given the debate concerning textual priority, Lilly aptly concludes that "it is premature to declare that the entire text of p. 967 traces back to a variant Hebrew Vorlage" (The Two Books of Ezekiel, 19).

17 See Klaus Koch, "Die Eigenart Der Priesterschriftlichen Sinaigesetzgebung," ZTK 55 (1958): 42; Menahem Haran, Temples and Temple-Service in Ancient Israel: An Inquiry into Biblical Cult Phenomena and the Historical Setting of the Priestly School (repr. ed.; Winona Lake: Eisenbrauns, 1995), 165, 175-88; Walter Houston, Purity and Monotheism: Clean and Unclean Animals in Biblical Law (Sheffield: JSOT Press, 1993), 221. 
tradition $(\mathrm{H})$, the latter of which consists of but is not limited to the Holiness Code (Lev 17-26), and both of these underwent exilic and postexilic redactions. Ezekiel represents yet another perspective, but its strong similarities to the priestly traditions are universally recognised. ${ }^{18}$ There are some differences of detail among the priestly literature regarding gradations of holiness. For example, according to the Holiness source $(\mathrm{H})$, the Israelite wilderness camp and the land of Israel are also holy, even beyond the tabernacle/temple court. However, the primary focus here is the temple, on which they all agree; therefore, concision prevents going into detail about the debates surrounding other distinctions.

At the lexical level, two word pairs, holy/profane (חלקדשי) and pure/impure (טמא/טהור) are important initial markers in priestly texts where grades of sanctity and impurity are of concern. ${ }^{19}$ The appearance of a single lexical indicator or concept related to the holiness/purity binaries has the capacity to evoke the broader conceptual framework in which they function. ${ }^{20}$ Together, these binaries relate to the portrayal of graded space as well as who or what may enter certain spaces. Accordingly, the boundary between holy and profane is central to the cult where sacred space is fiercely guarded from contact with a range of unholy, polluting agents. ${ }^{21}$ For instance, Ezek 43:7-9 warns that royal corpses must not be interred in close proximity to the deity (cf. also Lev 15:31 on the containment of impurity). Repeated references to the word pairs in priestly literature, especially in Lev 10:10 (H) and Ezekiel 22:26 and 44:23, reinforce their conceptual connection (see also Ezek 42:20; Lev 11:47; 20:25). ${ }^{22}$ These

18 Michael A. Lyons, From Law to Prophecy: Ezekiel's Use of the Holiness Code (LHBOTS; New York: T\&T Clark, 2009). Ezekiel quite likely relies on $\mathrm{H}$ where there are convergences between the two, though Knohl may be correct that Ezekiel informed later accretions in H. See Israel Knohl, The Sanctuary of Silence: The Priestly Torah and the Holiness School (Winona Lake: Eisenbrauns, 2007), 104-105, 202; Jacob Milgrom, Leviticus 1-16: A New Translation with Introduction and Commentary (AB 3; New York: Doubleday, 1998), 35-39; Milgrom, Leviticus 17-22 (AB 3A; New York: Doubleday, 2000), 1361-1364.

19 For a discussion of these terms and their relation to gradation, see P. Jenson, Graded Holiness: A Key to the Priestly Conception of the World (JSOTSup 106; Sheffield: JSOT Press, 1992), 40-55; Houston, Purity and Monotheism, 221-222; Olyan, Rites and Rank, 15-36.

20 Jenson, Graded Holiness, 36; Olyan, Rites and Rank, 15, 128n2; Nancy Bowen, Ezekiel (AOTC; Nashville: Abingdon, 2010), xix-xx.

21 Olyan, Rites and Rank, 16, 129n9. Olyan observes that the gradation implied between "holy" and "most holy" naturally presupposes a distinction between what is holy and profane. For this reason, he considers the holy/profane binary to be central to the conceptual framework as it gives meaning to the pure/impure binary as well as gradations associated with both holiness and impurity.

22 Where texts are cited from the Holiness source without further note in this paper, the reader should assume they are typically designated as such among those who accept 
texts make clear that distinctions are to be observed between the holy/profane and pure/impure in a cultic context to ensure proper care is taken to maintain sacred space dedicated to the deity. ${ }^{23}$

\section{Gradations of holiness in sacred space}

Graded space is most clearly articulated in priestly texts detailing the building of the wilderness tabernacle, though the priestly conception of gradation extends by analogy to the structure of Solomon's temple (1 Kings 6-7). The temple is

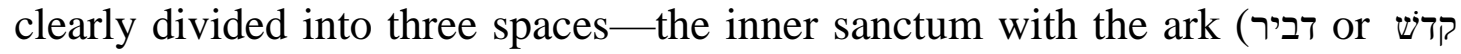
הקדשים; cf. $1 \mathrm{Kgs} 6: 16 ; 7: 50 ; 8: 6)$, the main room (היכל or), and the porch (אילם); $1 \mathrm{Kgs} 7: 21$ ). As with the tabernacle, a court, possibly with two parts, surrounds the temple proper with the altar for burnt offerings, molten sea and lavers (1 Kgs 7:23-26).

Sacred space is marked and reinforced in the priestly building accounts of the wilderness tabernacle (Exod 25-30; 35-40) in a number of ways. ${ }^{24}$ Lexically, the holy/profane binary gives rise to a "vocabulary of degree," where denote grades of sanctity for the most holy place and holy place (Exod 26:33). ${ }^{25}$ These terminological distinctions are not the only indicators of gradations, however. ${ }^{26}$ Exodus indicates finer gradations by describing spatial divisions as well as the quality of materials featured within each space. The פרכת curtain (Exod 26:33) divides between the inner and outer sanctum; screens separate between the entrance of the tabernacle (Exod 26:36;

the $\mathrm{P} / \mathrm{H}$ distinction. On Lev 10:10 as a Holiness text, see Knohl, The Sanctuary of Silence, 105; Olyan, Rites and Rank, 15.

23 Olyan, Rites and Rank, 15-17.

24 Knohl (The Sanctuary of Silence, 104-105), assigns the basic framework of Exod 25-30 (minus expansions) to $\mathrm{P}$ and 35-40 to $\mathrm{H}$. Milgrom (Leviticus 1-16, 36-37), however, questions whether Exod 35:4-40:38 is necessarily the product of $\mathrm{H}$, noting that ancient building inscriptions contain stylistic variation as well as both prescriptive and descriptive accounts of the construction. Whether Exod 35-40 is the product of $\mathrm{P}$ or $\mathrm{H}, \mathrm{H}$ appears to embrace and develop P's notion of graded sacred space by extending holiness to both land and people (Lev 18:24-28; 19:2; 20:8; 21:8).

25 Olyan, Rites and Rank, 38.

26 The terminology is not carried through systematically in priestly texts concerning spatial designations. For example, Leviticus identifies the adytum as both הקדש מקד מקדש הקדש may indicate graded space as well as the quality of the shrine as a whole and its sacred items; that is, the tabernacle, its contents and court, the altar, and the incense altar on the day of atonement are described as קדש קדשים in Exodus and Leviticus (Exod 29:31, 37; 30:10, 29; 40:10; Lev 6:9, 19 [Eng., 6:16, 26]; 7:6; 10:12-14, 17; 24:9). On terminological distinctions, see Wright, The Disposal of Impurity: Elimination Rites in the Bible and in Hittite and Mesopotamian Literature (SBLDS 101; Atlanta: Scholars Press, 1987), 233-234; Jenson, Graded Holiness, 89-91; Milgrom, Leviticus 1-16, 36. 
36:37) and the court (Exod 35:17); fabric hangings and pillars screen in the courtyard from the surrounding Israelite camp (Exod 27:8-18). The materials used for the tabernacle's construction reinforce the demarcation of graded areas; gold is used to craft the vessels and furniture in the inner and outer sanctum, and copper for items in the court. ${ }^{27}$

Finally, the structure of the priestly narrative arguably corresponds to the spaces it describes. As Jenson has pointed out, the narrative structure of Exod 25-31 emphasises graded space in that the most sacred items at the centre of the tabernacle are described first and with the greatest amount of detail. ${ }^{28}$ The same may be said of Ezekiel's temple vision (chs. 40-48), where the description begins with the centre and moves outward with diminished attention to detail. ${ }^{29}$ In this way, one may experience and notice the spatial contours of the temple as one progresses through the narrative. ${ }^{30}$

Social hierarchy is yet another aspect of the holiness framework in which gradation can be detected. In this framework, the deity is situated in the most honoured position, "preeminent in holiness and foremost in the hierarchy of status." ${ }^{31}$ Concerning social gradation, proximity to the divine presence correlates with one's role in the cult and determines social location. Olyan describes this in terms of "status gradation" based on a group's access to God, with priests at the top tier, followed by Levites, then Israelites. ${ }^{32}$ Priestly texts dictate that only priests may access the altar of burnt offerings (e.g. Num 18:17), and the high priest alone may enter the inner sanctum once a year to offer atonement for Israel (Lev 16:34). Priests are consecrated for service and wear

27 Haran, Temples and Temple-Service, 149-174.

28 Jenson, Graded Holiness, 94, 100.

29 K. R. Stevenson, Vision of Transformation: The Territorial Rhetoric of Ezekiel 40 48 (SBLDS 154; Atlanta: Scholars Press, 1996), 33-34.

30 Mary Douglas similarly explores the relation between the compositional structure of Leviticus and the tripartite structure of the tabernacle (Leviticus As Literature [Oxford: Oxford University Press, 2000], 58-59, 195-99, 218-30).

31 Olyan, Rites and Rank, 33, 140n105. Cf. also Houston, Purity and Monotheism, 54. Olyan aptly observes a connection between holiness, honour, and status. The interrelation is expressed in Lev 10:3 where God is said to be both sanctified (קדש) and honoured (כבד). Prophetic texts further emphasise honour due the deity, e.g., in sacrifice and the offering of holy food (Isa 43:23; Mal 1:6-7; 1 Sam 2:12-30).

32 Olyan, Rites and Rank, 29. For further discussion on the connection between social hierarchy and access to sacred space, see Susan Niditch, "Ezekiel 40-48 in a Visionary Context," CBQ 48 (1986): 218; Cook and Corrine, "Hierarchical Thinking," 12; David L. Petersen, "Creation and Hierarchy in Ezekiel: Methodological Perspectives and Theological Prospects," in Ezekiel's Hierarchical World: Wrestling with a Tiered Reality (ed. Stephen L. Cook and Corrine L. Patton; Society of Biblical Literature Symposium Series 31; Atlanta: Society of Biblical Literature, 2004), 176-177. 
holy garments befitting their honoured status while performing ritual duties. ${ }^{33}$ They are ritually fitted to occupy the most sacred of spaces. The priesthood itself reflects a graded or tiered hierarchy, with the high priest, Aaronide priests, and Levites at different ranks. The Levites are commissioned to guard the entrance to the tabernacle but do not have access to its holy contents or to priestly consecration for service. ${ }^{34}$ Non-priestly Israelites have even less access to sacred space, permitted only into the court to participate in the slaughter of sacrifices (Lev 1:2ff). In this priestly framework of social hierarchy, foreigners occupy a position on the outer periphery due to their limited access to the cult. ${ }^{35}$

Gradations based on the purity/impurity binary add yet another layer to the priestly holiness framework. While priestly texts communicate distinctions between major and minor impurities, a "vocabulary of degree" such as that used to define holy space and persons is lacking for the range of defilements. The degree of defilement is instead indicated by other factors, such as the source of impurity, extent of possible contagion, requirements for purification, and length of time it may take one to regain purity and access to the normal range of social and cultic participation. ${ }^{36}$ All impure states restrict access from the tabernacle/temple until one is restored to a state of purity. ${ }^{37}$ Failure to follow through with the required purification may result in debilitating consequences;

33 For priestly anointing and consecration, see Exod 28:40-43; 30:26-30; 40:12-15; Lev 8:22-30, which correlate with that of the tabernacle and its contents (Exod 29:44; 30:26-29; 40:9-11; Lev 8:10-11). Regarding priestly attire, the high priest's breastplate is worked in gold and precious stones (Exod 28), corresponding to the material gradation of the tabernacle. The high priest's linen vestments worn in the inner sanctum may not be worn elsewhere (Lev 16:23). Furthermore, Aaron's holy (קדשר) garments are associated with his honoured (כבד) status (Exod 28:2).

34 Numbers 3:6-9; 8:9-18; and 18:2-4 (but cf. 2 Chron 23:6 where the Levites are considered holy, along with the priests).

35 Regarding access to the tabernacle, see Num 1:51; 3:10, 38; $18: 7$ where the nonIsraelite (זר) is kept at a distance from the cult, and the foreigner (בן־נכר) is excluded from partaking in Passover (Exod 12:43-49). For further comment on social gradation with foreigners/nations at the outermost periphery, see Jenson, Graded Holiness, 116117. Olyan, however, notes the complexity in determining the exclusion of foreigners from the cult (Olyan, Rites and Rank, 66-68, 154n22).

${ }^{36}$ Cf. Jenson, Graded Holiness, 45, 138-39; Olyan, Rites and Rank, 38-39. A "vocabulary of degree" with regard to graded impurities is articulated in rabbinic discourse on defilements; e.g., corpse defilement is אב אבות הטומאה; major impurity is אב הטומאה; טומאה See m. Kelim 1:1-4; m. Zabim 5:11; b. B. Qam. 2b; b. Pesah 14b, 17a.

37 For example, Lev 22:4-7 outlines impure states (scale disease, corpse contamination, seminal emission) that prevent a priest's access to holy food until purified. Similarly, the parturient is restricted from the sanctuary until her purification period is complete (Lev 12:4). 
for example, those who fail to complete the purification process for corpse contamination, which defiles the sanctuary, are subject to the kāretet penalty, that is, are cut off from the assembly, according to Num 19:20. ${ }^{38}$

\section{Gradations of holiness in Ezekiel}

The text of Ezekiel provides several clues that its spatial arrangements concerning temple, society, and cosmos have been shaped by priestly ideology. The temple remains central to Ezekiel's rhetoric, given that the priestly dichotomies (טמא/טהור and steem to function as a framework for the book as a whole, especially as a means by which to make sense of the exile and to describe social and spatial gradation. ${ }^{39}$ Ezekiel draws repeatedly on the command to maintain boundaries between sacred and profane, and between pure and impure expressed in Lev 10:10 ("You are to distinguish (בדל

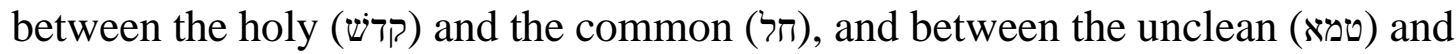
the clean (טהור)"). The necessity of making these distinctions is expressed once as a condemnation (Ezek 22:26) and once as a command (Ezek 44:23). For Ezekiel, the "whole cultic enterprise unravels" when these distinctions are not maintained. ${ }^{40}$ Ezekiel $8-11$ vividly illustrates that sanctum contagion has brought about this result: YHWH's "glory" (כבוד) departs from the tarnished temple, no longer able to house the divine presence. ${ }^{41}$

The clearest picture of spatial and status gradation in the book of Ezekiel not surprisingly derives from the temple vision of chs. $40-48 .{ }^{42}$ There, graded areas in the temple complex and its environs are ordered both vertically and horizontally, primarily marked by structural descriptions and somewhat by lexical cues. ${ }^{43}$ Like the priestly tabernacle and Solomon's temple, Ezekiel's

38 כפכָרָת is post-biblical (Talmudic); see Jastrow, 674. For other purification violations, see Lev 7:20-21; 22:3-9; such violations incur the same penalty as prohibited impurities. See also Jacob Milgrom, "The Graduated Hatta ${ }^{\prime} t$ of Leviticus 5:1-13," JAOS 103 (1983): 251-52. In the case of required sacrifice in Lev 5:2-4 for unintentional impurity violations, Milgrom suggests that the concern is with secondarily contracted impurities, which may not have been recognised soon enough to fulfil purity rites.

39 Milgrom, Leviticus 1-16, 982; Bowen, Ezekiel, xix, xxi. For a lengthy discussion on the pervasive function of the holiness and purity binaries in Ezekiel, see also Andrew Mein, Ezekiel and the Ethics of Exile (Oxford: Oxford University Press, 2006), chs. 4 5.

40 Olyan, Rites and Rank, 15.

41 Milgrom, Leviticus 1-16, 982; Mein, Ezekiel and the Ethics of Exile, 153.

42 For a brief comparison between Ezek 40-48 and graded areas in the tabernacle and Solomon's temple, see Olyan, Rites and Rank, 22-24.

43 Ezekiel is consistent with priestly texts that use קדש הקדשים/ קדוש to mark graded spaces as well as to denote the holy quality of the temple and its environs (43:12; 45:3; 48:12). 
temple contains the three primary graded spaces - the innermost room ( קדש (הקדשים), main temple hall, and two-part court (Ezek 40-42). Its structural features, however, add nuance to spatial boundaries by the use of progressively narrowing entrances and steps to signal movement upward and inward into the holiest space $(40: 21,26,31,34,37,49) .{ }^{44}$ The court is divided between inner and outer areas, with massive gates to control access, and a wall encloses the entire complex to separate the holy (קדוש) from the profane (42:20; cf. 40:5). The "portion" (תרומה) in which the temple complex is situated is also stratified, with holy areas reserved for priests and Levites (45:4-5), and "profane" (חל) space for city (48:15) and prince (45:7) ${ }^{45}$ The descriptive account suggests at least five or six graded areas in the temple complex and its environs. ${ }^{46}$ The portrayal is more an ideological construct than a precise architectural model, designed to emphasise the nature of controlled access and sacred boundaries. ${ }^{47}$ Like priestly literature, Ezek 40-48 also reflects status gradations correlating to its graded areas, albeit in a somewhat modified form.

Graded structures may also be detected in the book's cosmic geography. On the whole, Ezekiel's vertically tiered cosmos ranging from heaven, to earth, to underworld corresponds to that of Mesopotamian cosmic geography; both feature the blue floor of heaven, a boundary marker between heaven and earth (Ezek 1:26-28, 10:1; cf. Exod 24:9-10). ${ }^{48}$ Cook contends that the priestly

44 Moshe Greenberg, "The Design and Themes of Ezekiel's Program of Restoration," Int 38 (1984): 191-192; Cook and Patton, "Hierarchical Thinking," 14; Michael Konkel, "The System of Holiness in Ezekiel's Vision of the New Temple (Ezek 40-48)," in Purity and the Forming of Religious Traditions in the Ancient Mediterranean World and Ancient Judaism (ed. C. Nihan and C. Frevel; Dynamics in the History of Religions 3; Leiden: Brill, 2012), 434.

45 Though not overtly identified as such, the prince's portion is likely profane, like the city; cf. Rimon Kasher, "Anthropomorphism, Holiness and Cult: A New Look at Ezekiel 40-48," ZAW 110 (1998): 207; Jonathan Z. Smith, To Take Place: Toward Theory in Ritual (Chicago: University of Chicago Press, 1992), 61-62; Stevenson, Vision of Transformation, 109-123. However, Greenberg ("Design and Themes," 202) suggests a tertiary holiness implied in the city's proximity to the temple, along with its name, "YHWH is there."

46 Cook and Patton, "Hierarchical Thinking," 13-14; Olyan, Rites and Rank, 19-24. Olyan identifies the graded spaces - the holy of holies, central temple chamber, inner court, outer court, priests' territory, and the Levites' territory.

47 Greenberg, "Design and Themes," 192-193; Konkel, "The System of Holiness," 435.

48 Horowitz, Mesopotamian Cosmic Geography, 9. The Sinai theophany in Exod 24:9-10 also implies a similar kind of vertical gradation according to which Moses alone may ascend Sinai to meet with God; by comparison, he alone may enter the tabernacle's inner sanctum (Exod 19:20; 25:22; Num 7:89). Cf. Milgrom, Leviticus 116, 142-143; Nahum M. Sarna, Exodus (Philadelphia: JPS, 1991), 105. 
holiness infrastructure, with its strictures concerning the separation between the holy and the profane, governs Ezekiel's picture of a graded cosmos. ${ }^{49}$ The divine presence makes an appearance in the heavens (Ezek 1); cherubim function as throne bearers as they accompany the portable divine presence above the expanse (רקיע) (Ezek 1:5-14; 10:15, 20-22). Cook observes that, as guardians of sacred boundaries (cf. 28:11-19), cherubim function as an "ideal tool for depicting a storied cosmos, with graded levels of closeness to God." 50

\section{CIRCUMCISION, FOREIGNERS AND BURIAL}

The repeated references to uncircumcision (ערלים) to characterise the foreign nations in Ezek 32 serve as a bridge between the concepts of (un)holiness/(im)purity and status in the underworld. As a marker of both ethnic identity and cultic purity, it is well suited to do so. This is not yet a marker of rank. After all, circumcision is a binary state. One either is or is not circumcised, therefore, none of the nations in Ezekiel's underworld can be any more or less exposed to uncircumcision. Rather, all the nations in the Pit (except the gibbôrîm) are equally exposed to such improper burial.

Of the 34 biblical occurrences of the adjective ערל, nearly half occur in Ezekiel (Ezek 28:10; 31:18; 9x in 32:17-32; 4x in 44:7, 9), and the term always serves as a designation for foreigners. ${ }^{51}$ It was often used to describe the Philistines, one of Israel's earliest paradigmatic enemies (cf. Judg 14:3; 15:18; 1 Sam 14:6; 17:26, 36; 18:27; 31:4; 2 Sam 1:20; also 1 Chron 10:4). Circumcision became a "sign of the covenant" (אות ברית; Gen 17:11), ${ }^{52}$ required to gain access

49 Stephen L. Cook, "Cosmos, Kabod, and Cherub: Ontological and Epistemological Hierarchy in Ezekiel," in Ezekiel's Hierarchical World: Wrestling with a Tiered Reality (ed. Stephen L. Cook and Corrine L. Patton; Society of Biblical Literature Symposium Series; Atlanta: SBL, 2004), 184-186.

50 Cook, "Cosmos, Kabod, and Cherub," 179. Ezekiel 28:11-19 emphasises the boundary keeping role of cherubim by referencing the "holy mountain of God" ( הר קדש in ארץ in its 28:17, the space to which the offending being (cherub or primordial human, depending on one's preference for the MT or LXX reading) is cast in its profane (ה) state. Considering that ארץ is cognate with the Akkadian erșetu and Ugaritic ars (common names for the underworld), ארץ may indicate the same location in Ezek 28:17 (cf. also Jonah 2:7; Pss 22:30; 71:5; Jer 17:15; Horowitz, Mesopotamian Cosmic Geography, 268; Hays, Death in the Iron Age II, 177). If so, this adds to the picture of a graded, tiered cosmos at work in the text of Ezekiel in that the disgraced figure of Ezek 28 is banished ("profaned") to the underworld.

51 These counts reflect the emendation of מערלים in Ezek 32:27 to מעולם.

52 The juncture in Israelite religion when circumcision took on covenant symbolism is not clear and largely depends on the date one assigns to priestly texts. For example, while Knohl classifies Exod 12:44, 48 as a product of $\mathrm{H}$ and Gen 17:10-14 as a product 
to Israel's cultic life. ${ }^{53}$ It almost certainly gained greater significance as an ethnic marker in the exilic period or later, whenever the practice began. ${ }^{54}$ "Uncircumcised" seems eventually to have expanded into an all-purpose term of denigration for foreigners who were excluded from the covenant. ${ }^{55}$

Ezekiel 32's use of the term "uncircumcised" seemed odd to some scholars of past generations, such that they sought to argue that the term means something else here, but it is better to understand ערלים as simply indicating uncircumcision. ${ }^{56}$

The nations in Ezekiel's underworld are relegated to an inglorious postmortem existence set apart from peoples who practice the rite. In 28:10 as well,

of P (Knohl, The Sanctuary of Silence, 104), Olyan attributes most of Gen 17:9-14 to an exilic strand of $\mathrm{H}$ on the basis of terminology (Olyan, Rites and Rank, 66-67, 15455n23). Olyan's discussion of לדרתיכם as a marker of H (see also Knohl, Sanctuary of Silence, 12-14, 46-55), however, contrasts with those who consider it reflective of the early character of P. Cf. Avi Hurvitz, A Linguistic Study of the Relationship between the Priestly Source and the Book of Ezekiel (CahRB 20; Paris: Gabalda, 1982), 98-101; Milgrom, Leviticus 1-16, 614.

53 Cf. Michael V. Fox, "Sign of the Covenant: Circumcision in the Light of the Priestly 'ôt Etiologies," RB 81/4 (1974): 594-595; David A. Bernat, Sign of the Covenant: Circumcision in the Priestly Tradition (AIL 3; Atlanta: Society of Biblical Literature, 2009), 37-38.

54 The notion that the rite took on prominence in Israelite religion during the exilic period or later is frequently asserted. Cf. Julius Wellhausen, Prolegomena to the History of Israel (trans. J. S. Black and A. Menzies; Edinburgh: Black, 1885; repr., Eugene: Wipf and Stock, 2003), 116, 341, 492; Klaus Grünwaldt, Exil und Identität: Beschneidung, Passa und Sabbat in der Priesterschrift (BBB 85; Frankfurt am Main: Anton Hain, 1992), 1, 47-56; Olyan, Rites and Rank, 154-155n23; William H. Propp, "Circumcision: The Private Sign of the Covenant," Bible Review 20/4 (2004): 22-29; Simon C. Mimouni, La Circoncision dans le monde Judéen aux époques Grecque et Romaine: Histoire d'un conflit interne au Judaïsme (CREJ; Paris: Peeters, 2007), 3940.

55 Cf. also Bowen, Ezekiel, 202.

56 Early critical scholars tried in various ways to argue that ערלים did not mean "uncircumcised" at all, but was simply a term for the dead. One reason for the objections is that the Egyptians, Edomites and other neighbours of Israel in fact practiced circumcision (see also Jer 9:25-26). Halévy argued that it was cognate with Akkadian arallû (Halévy, Mélanges de critique et d'histoire relatifs aux peuples sémitiques [Paris: Maisonneuve, 1883], 158, 184n1, 293). Cf. also Fritz Hommel, Grundriss der Geographie und Geschichte des alten Orients (München: C. H. Beck'sche, 1904), 124n1. The term arallû refers to the underworld as a place in Akkadian and is not applied to the individuals who dwelled there (CAD A/2, 226-227.) Furthermore, one expects an Akkadian word resulting from the loss of an initial ProtoSemitic 'ayin to have an e-vowel (e.g., Akk. eperu vs. Heb. 'āpār or Akk. emēdu vs. 
Ezekiel condemns the prince of Tyre to "die the death of the uncircumcised" (מותי ערלים תמות), which seems to be shorthand for being sent to an unhappy afterlife in the Pit (28:8). It is fairly widely agreed that circumcision was probably seen by Ezekiel as a necessity for a happy afterlife, and for him to describe the once-mighty nations as being buried with the uncircumcised was to condemn them to an ignominious, shameful death - whether by contact or by association. $^{57}$

\section{E THE INHABITANTS OF THE UNDERWORLD IN EZEKIEL 32}

Ezekiel's graded, tiered cosmos governed by the priestly holiness matrix extends to a tiered underworld where the lot of the foreign nations receives special attention. Ezekiel 32:17-32 concludes the book's oracles against the nations (chs. 25-32) by describing the fate of seven foreign groups in the underworldEgypt, Assyria, Elam, Meshech-Tubal, Edom, the "princes of the North," the Sidonians. In priestly fashion, the book repeatedly emphasises that the judgment of the nations is God's way of manifesting holiness: "They shall know that I am the LORD when I execute judgments in it, and manifest my holiness (נקדשישי) in it" (28:22; see also 20:41; 36:23). Parallel rhetoric occurs in Lev 10:3 where the deity manifests holiness (אקדש) in the punishment of Nadab and Abihu for failing to attend to the tabernacle's sanctity.

\section{The gibbôrîm in Sheol}

In Ezek 32:17-32, Egypt is the focus, the new arrival to the underworld, like the so-called "king of Babylon" in Isa 14. The parallels between the passages are notable. Both comprise a mock-lament within a mock-lament - that is, each begins with a call for its audience to lament ("take up this $m \bar{a} \bar{s} \bar{a} l$ " in Isa 14:4;

Heb 'āmad) — not an a-vowel like arallû. A related theory reinterpreting ערלים drew on the parallelism between it and חללים (esp. Ezek 28:8, 10; 31:18; and 32:21), using the latter term to interpret the first with the sense that חללים (and therefore, ערלים) implies a fallen soldier left exposed without burial rites. See, for example, Heinrich Ewald, Die Propheten des alten Bundes (Stuttgart: Adolph Krabbe, 1841), 2:318, 333; Ferdinand Hitzig, Der Prophet Ezechiel (Leipzig: Weidmann'sche Buchhandlung, 1847), 214, 249-250. However, since ערל clearly means "uncircumcised" in numerous other biblical texts referring to foreign nations, it would have been very confusing to use it differently in Ezekiel. Thus, with good reason, neither proposal has met with much acceptance.

57 The opposition between uncircumcision and proper Jewish burial was made much more explicit in later sources. For example, Jubilees 15:26-27 asserts the necessity of circumcision for the afterlife. It was later echoed in $b$. Sanh. $110 \mathrm{~b}$ where it is said that the uncircumcised have no place in the world to come. Conversely, Genesis Rabbah 48:8 says that Abraham sits at the gate of Gehenna and prevents any circumcised Jew from descending there. 
"Wail, O son of man" in Ezek 32:18), and within each lament the denizens of the underworld also derisively greet the newcomers (Isa 14:9-10; Ezek 32:21). ${ }^{58}$ In Isa 14:9, "Sheol below rouses itself to greet you," and those who are there are described in a threefold way_-"Rephaim," "leaders (עתודים, "male goats") of the earth," and "kings of nations" (מלכי גוים). Sheol can be seen as the antechamber of the underworld, the place where nobility greets new arrivals. ${ }^{59}$

The distinction between Sheol and the Pit in Ezek 32 might therefore be compared to the Mesopotamian distinction between Ganzer, the gated palace of the netherworld where its rulers live, and the inner parts of the netherworld where the common dead live. The gibbôrim are not portrayed as rulers, but they are clearly of higher status (v. 27), and they greet the newly arrived Egyptians (v. 21).

In Ezek 32, the "mighty chiefs/rams" (אלי גבורים) are the only ones in the underworld who are described as being in Sheol, while the other nations are said to be in the Pit (בור). The two are sometimes used interchangeably elsewhere in the book, for example, in 31:16, but not in ch. 32. This is carried through quite systematically. Egypt is said to go to the Pit (32:18), as are Assyria (v. 23), Elam (v. 24), Edom (v. 29), the north, and Sidon (both v. 30). Only in the case of Meshech and Tubal is omitted. ${ }^{60}$

Sheol is sometimes described as the destination of the dead generally, though it is almost always the Israelite/Judahite dead who are said to go there. Sheol is a feared destination, even if being sent there is not described as a punishment, that is, compared to the living. Sheol was not the worst or most distant destination in death; it was still viewed as a place in some sense near to the living. Matthew Suriano has argued that Sheol mythologically symbolised the liminal state of waiting, analogous to the tomb bench on which the dead temporarily reposed before being gathered to the charnel pit. ${ }^{61}$

The widely accepted text-critical emendation of מעולם to מערלים, supported by LXX, indicates an allusion to Gen $6: 4 .{ }^{62}$ Thus, the mighty ones are the

58 See Gale A. Yee, "The Anatomy of Biblical Parody: The Dirge Form in 2 Samuel 1 and Isaiah 14," CBQ 50 (1988): 565-586.

59 Marzouk, Egypt as a Monster, 225.

60 The reasons for this omission are not entirely clear. Cook has suggested that it is because they recur in Ezek 38-39, and thus cannot yet be finally consigned to the Pit.

${ }^{61}$ Matthew Suriano, A History of Death in the Hebrew Bible (Oxford: OUP, 2018), 243-247.

62 C. H. Cornill, Das Buch des Propheten Ezechiel (Leipzig: J. C. Hinrichs, 1886), 390; Boadt, Ezekiel's Oracles Against Egypt, 164-165; Walther Zimmerli, Ezekiel 2548 (Herm.; trans. James D. Martin; Philadelphia: Fortress, 1983), 168n27; Block, The Book of Ezekiel, 2:220n54, 228-229. 
Nephilim who lived before the circumcision stipulation of the Abrahamic covenant (Gen 17). There is little doubt that the MT's מערלים was influenced by the term's ubiquity elsewhere in the passage; the supposedly privative use of in מערלים would constitute very unusual syntax. ${ }^{63}$

\section{The other nations in the Pit}

Moving from Sheol to the Pit, one encounters a dedicated section for each nation, introduced by the term שמה שם "there." Such use of demonstrative pronouns is also characteristic of "tours of hell" both before and after Ezekiel's time.$^{64} \mathrm{It}$ was not used for the gibbôrim, which again emphasises that they are not in the same place as the punished. Verse 27 emphasises that point: "they do not lie with the fallen warriors of long ago who went down to Sheol."

The most basic feature that indicates the ranking of each nation in the underworld is the length of the section. Just as priestly authors dedicated longer descriptions to holier parts of the tabernacle and temples, so too Ezekiel uses more words for the greater evils in the underworld. Chart 1 below shows the number of morphemes and the terms used for each nation. ${ }^{65}$

63 The further textual emendation from MT צונותם to importance to this interpretation, but there is no textual support for the change among the ancient versions. It was proposed by Cornill, Das Buch des Propheten Ezechiel, 390 , and has been widely adopted. Recent exceptions, however, include JPS Tanakh, the NASB, Volkmar Premstaller, Fremdvölkersprüche des Ezechielbuches (FB 104; Würzburg: Echter, 2005), 197, 204; Doak, "Ezekiel's Topography," 617-619.

64 Himmelfarb, Tours of Hell, 2-7, 41-67; Sanders, "The First Tour of Hell," 162.

65 Prefixed conjunctions, prepositions, and articles, and suffixed prepositions are counted as individual morphemes. However, the direct object marker and the waw of the preterite verb are excluded. For the sake of simplicity and transparency, the MT is analysed without emendations. 
506 Wells \& Hays, "Degradation," OTE 33/3 (2020): 490-514

\begin{tabular}{|c|c|c|c|c|c|c|c|c|c|c|c|}
\hline & $\begin{array}{l}\text { Mor- } \\
\text { phemes }\end{array}$ & $\begin{array}{l}\text { Asso- } \\
\text { ciates }\end{array}$ & שאול & בור & חללים & נפרים & חללי & חתית & ערלים & שם & שמה \\
\hline $\begin{array}{l}\text { Egypt } \\
(32: 18-21)\end{array}$ & 46 & המון & & $\mathrm{x}$ & $\mathrm{x}$ & $\mathrm{x}$ & $\mathrm{x}$ & $\mathrm{x}$ & $\mathrm{x}$ & & \\
\hline $\begin{array}{l}\text { Assyria } \\
(32: 22-23)\end{array}$ & 42 & קהל & & $\mathrm{x}$ & $\mathrm{x}$ & $\mathrm{x}$ & & $\mathrm{x}$ & & $\mathrm{x}$ & \\
\hline Elam (32:24) & 36 & 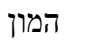 & & $\mathrm{x}$ & $\mathrm{x}$ & $\mathrm{x}$ & & $\mathrm{x}$ & $\mathrm{x}$ & $\mathrm{x}$ & \\
\hline Elam $(32: 25)$ & 37 & 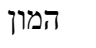 & & $\mathrm{x}$ & $\mathrm{x}$ & & $\mathrm{x}$ & $\mathrm{x}$ & $\mathrm{x}$ & & \\
\hline $\begin{array}{l}\text { Meshech- } \\
\text { Tubal } \\
(32: 26) \\
\end{array}$ & 24 & המון & & & & & $\mathrm{x}$ & $\mathrm{x}$ & $\mathrm{x}$ & $\mathrm{x}$ & \\
\hline Edom (32:29) & 24 & & & $\mathrm{x}$ & & & $\mathrm{x}$ & & $\mathrm{x}$ & & $\mathrm{x}$ \\
\hline $\begin{array}{l}\text { Princes of the } \\
\text { north } \\
\text { Sidonians } \\
(32: 30)\end{array}$ & $\begin{array}{l}30 \div 2 \\
=15\end{array}$ & & & $\mathrm{x}$ & & & $\mathrm{x}$ & $\mathrm{x}$ & $\mathrm{x}$ & & $\mathrm{x}$ \\
\hline
\end{tabular}

\section{Chart 1: Hierarchy of nations in Ezekiel 32}

The Elam passage has been preserved in two different forms, now appearing as a kind of doublet. ${ }^{66}$ With the reduction of this doublet (as the LXX models), each nation has a shorter mention than the last. Multiple princes of the north and Sidonians are all grouped into one final section; although this section is slightly longer in length, divided among its subjects it gives each one less attention than the nations that are discussed individually.

Assyria is the most emphatically condemned nation in the underworld (32:22-23). The Assyrians are buried in the "distant parts of the Pit" (ירכתי בור). If the holiest place in the Temple was the "holy of holies," then this is the "depth of depths." It is also an unmistakable allusion to Isa 14:15's threat against the Mesopotamian king that he would be brought down to the same place; these are the only two occurrences of the phrase in the Bible. This intertextual allusion is also a curse of special vehemence. The extremities are a place of banishment. Whether or not one can correlate the biblical "distant parts of the Pit" with the Sumerian "bottom of the netherworld" (dúr.kur.ra), one can say that from an ANE perspective, those that are in the farthest part of the netherworld are the farthest from the world of the living; they are the "deadest of the dead." Those

66 The "doublet" is addressed in varying ways by commentators given the redundancy in MT 32:24-25 and shortened reading in LXX 32:25. For example, While Block, The Book of Ezekiel, 2:221-223, identifies vv. 24-25 as a unit dedicated to Elam, Zimmerli, Ezekiel, 2:167 and Boadt, Ezekiel's Oracles against Egypt, 158-159, opine that v. 25 may have originally described Meshech-Tubal or Egypt as the new arrival to the Pit. 
who had been the most powerful (and thus abusive) in history are singled out for the greatest punishment. The crueller they come, the deeper they fall.

Other differences and patterns in the passage's language emerge that allow one to assign rank to the various nations. The first difference confirms קהל Assyria's unique status as the nadir of unholy evil. Only Assyria has a ("assembly," vv. 22-23), whereas Elam and Meshech-Tubal each have a תמון ("horde"), and the rest have no associates. Of course, המון an are common nouns that may be used in different ways in different contexts; but in 32:3, קהל a of many (or great) nations, suggesting that Ezekiel uses קהל as the wider and more formal term. Thus, the Assyrians are the largest power and the most condemned among the ranks of the underworld.

Elam is close to Assyria in degradation, but it is treated more briefly, and has only a המון rather than a קרלץ תחתיות ("lower land"), but this is a less extreme designation than the "extremities of the Pit." It is not clear that the "lower land" is worse than or different from the "Pit" (בור) with which it is equated in $32: 24$ as well as $26: 20 ; 31: 14,16 .{ }^{67}$ As with Akk. šaplâtu, this simply seems to be a term for the lower regions of the earth. ${ }^{68}$

Elam mostly receives mere passing mentions in the Bible apart from this passage and Jer 49:34-39. Since it lay on the far side of Mesopotamia, it was never a primary threat to the kingdoms of Israel and Judah. Nevertheless, it was an empire of quite significant power. ${ }^{69}$ Another possible factor in Elam's prominence in Ezekiel's hell is the corpse abuse which the Elamite kings had famously suffered within living memory of Ezekiel's career. Elam had been a persistent threat to the Neo-Assyrian Empire, therefore, in 653 B.C.E., Aššurbanipal tried to wipe it out permanently. ${ }^{70} \mathrm{He}$ not only plundered and destroyed Elam's cities, he also exhumed its royal tombs in order to "lay restlessness on their spirits" by denying them care in the afterlife. ${ }^{71}$ Since these

67 Cf. Boadt, Ezekiel's Oracles against Egypt, 161.

68 See Horowitz, Mesopotamian Cosmic Geography, 292; Knut Tallqvist, Sumerischakkadische Namen der Totenwelt (STOr 5/4; Helsinki: Societas Orientalis Fennica, 1934), 11ff.; Hayim Tawil, Akkadian Lexical Companion for Biblical Hebrew (New Jersey: Ktav, 2009), 35-36.

69 See, e.g., D. T. Potts, Archaeology of Elam: Formation and Transformation of an Ancient Iranian State (Cambridge: Cambridge University Press, 2015), 249-306.

70 As part of that effort, Aššurbanipal is said to have deported Elamites to Samaria; see Ezra 4:10, which refers to him as Osnappar.

71 Annals, col. 6, lines 70-76. See Maximilian Streck, Assurbanipal und die letzten Assyrischen Könige bis zum Untergange Ninivehs (1916; repr., Leipzig: Zentralantiquariat, 1975), 54-57. He also killed and beheaded Elam's reigning king, 
events were prominently reported in royal propaganda that was designed to be publicised, Elam may have been a well-known example of a formerly powerful nation consigned to a miserable afterlife.

Meshech-Tubal is treated as a single entity, as indicated by the singular pronouns in MT 32:26. ${ }^{72}$ Meshech and Tubal were known as peoples in Asia Minor, according to both Herodotus (7.78) and Josephus (Ant. 1.124) ${ }^{73}$ Thus, they were heirs to the legacy of the Neo-Hittite kingdoms. ${ }^{74}$ Ezekiel 32's passage on Meshech-Tubal is short, like those of the lesser nations that follow, but it may be ranked differently on two grounds. First, like Assyria and Elam, it has associated hordes (המון); and second, it is placed in the first set of nations, prior to the allusion to the gibbôrim.

Edom is the final nation included individually in the list and its significance is explained by the numerous biblical references to the Edomites' role in or around the fall of Jerusalem in 586 (Ps 137:7; Isa 34; Jer 49:7-22; Lam 4:21-22; Ezek 25:12-14; 35:15; 36:5).

Summing up the list, "all the Sidonians" and the "princes of the north" שמה are presented quite briefly, in combination under a single (נסיכי צפון) subheading. The term נסיכי seems to refer to Aramean and other Levantine tribal chieftains (Josh 13:21; Ps 83:12; Mic 5:5), potentially distinct groups from Sidonians. Therefore, this is a disparate assembly.

In sum, then, spatial distinctions correlate with social hierarchy in Ezekiel's underworld, much like in priestly conceptions of rank and order-the gibbôrim in Sheol, the antechamber or reception hall of the netherworld, at least four layers or circles in "the Pit," and Assyria flung to the farthest edges. Within the main section of the Pit, finer gradations of rank are perceptible than has previously been argued. The nations are not ranked based on their activities, but on their prominence. Assyria, as the only "world superpower," stands alone.

Te'umman, then hung the head up on a tree; this would certainly have impeded his afterlife rest as well.

72 That is, despite the Versions' insertion of a conjunction between the two terms. The entities are separated by a conjunction also in Ezek 27:13; 38:2 and 39:1. MeshechTubal may be joined in MT 32:26 to achieve a stylised list of seven nations in the Pit; cf. Block, The Book of Ezekiel, 2:224; Boadt, Ezekiel's Oracles against Egypt, 151.

73 D. W. Baker, "Meshech (Person)" in The Anchor Bible Dictionary (ed. David N. Freedman; New York: Doubleday), 711.

74 It is striking that the rare term התית is used for "terror" in this passage, since Ezekiel is also one of the only places where the identical feminine form of Hittite (thus "Hittite woman") appears. The latter is famously used to insult the people in Ezek 16:3, 45: "Your mother was a Hittite." However, חתית, "terror," has a good Akkadian cognate in hattu, which could have influenced Ezekiel, therefore, the similarity may be accidental. 
Elam was a regional empire that rivalled Assyria, while the rest were local powers.

Figures 1 and 2 below schematise this analysis and compare the structures of Ezekiel's underworld to those of the Temple. In both figures, holiness or purity decrease as one moves from right to left.

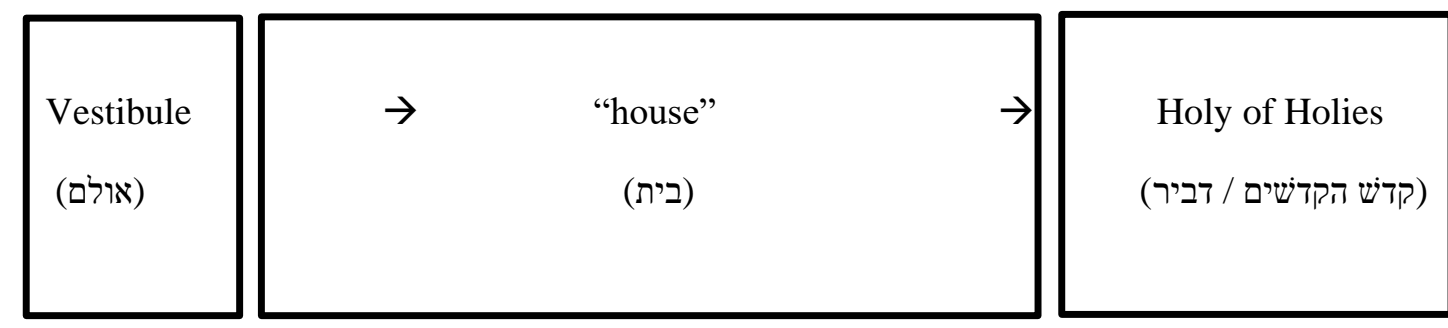

Fig. 1. Solomon's Temple

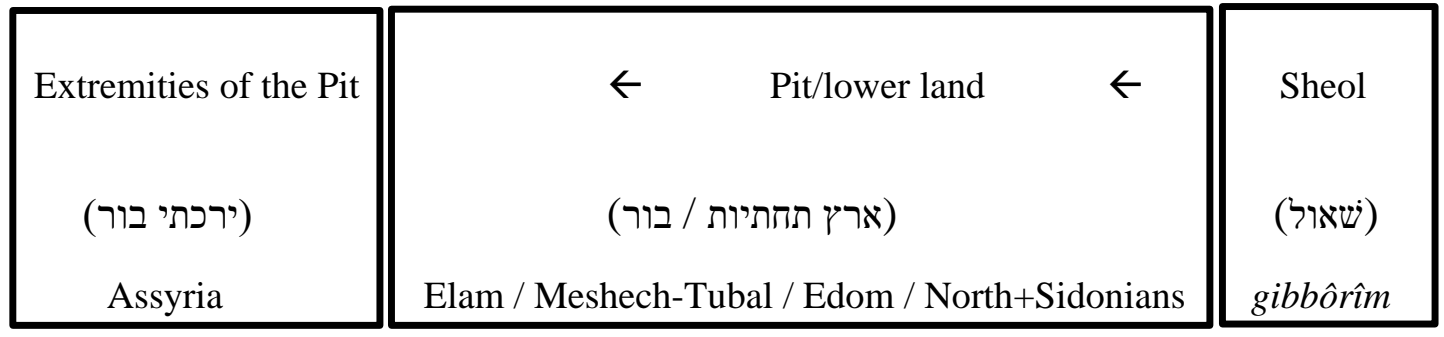

Fig. 2. Ezekiel's Underworld

In Ezek 32, Egypt, as the newcomer and the recipient of this "tour of hell," is not necessarily ranked like the others. It is not part of the tour of nations introduced by the demonstrative particles. On the other hand, it is the main focus of the passage and (as Chart 1 reflects) the recipient of the most verbiage; this emphasis would be more pronounced if vv. 31-32 were also added into the count. Furthermore, Egypt is welcomed to the underworld with an insult, just like the king in Isa 14.

\section{F CONCLUSION}

Comparative data from Mesopotamian religions led us to ask whether Ezekiel's underworld might also be characterised by hierarchy and gradation. A close literary analysis demonstrated that indeed it has three primary graded spaces namely Sheol, the Pit, and the extremities of the Pit. Egypt is introduced to the underworld in a "tour of hell" in which Assyria is singled out as inhabiting the extremities of the Pit, while only the gibborim are identified as dwelling in Sheol, the antechamber of the underworld. The Mesopotamian underworld was also tiered, and this may represent another instance of subtle Mesopotamian influence on Ezekiel.

Sacred spaces in the Bible are characterised by gradations of holiness, therefore, Ezekiel's underworld is in effect a mirror image of them; it can be 
imagined, heuristically, as a kind of unholy temple. Like Ezekiel's underworld, each of the three primary descriptions of holy space in the Hebrew Bible (the Priestly tabernacle, Solomon's temple, and Ezekiel's temple) has three primary graded spaces (inner sanctum, outer sanctum, and court). As one progressed deeper into the sanctuaries, holiness and purity increased; as one moved deeper into Ezekiel's underworld, unholiness and degradation increased.

Like the tabernacle and temples, Ezekiel's underworld also has further gradations within the primary space assigned to foreign nations listed in order of decreasing might (Elam, Meshech-Tubal, Edom, the "princes of the north," and Sidon). These finer gradations of unholiness are marked by factors such as the length of the passage dedicated to a nation and the presence of associates in its sphere of influence.

All of the underworld and its inhabitants are unholy, according to Ezekiel; they are all characterised by association with the impurity of uncircumcision. In a mirror image of the way that the whole temple is holy (קדוש), yet there are gradations within it, so the underworld is all "uncircumcised" (ערל), yet there are gradations within it.

Among these other conclusions, we may thus note that Ezekiel's notion of the divine will and plan was more ethnocentric than others (e.g., Isa 56:1-8). As far as we can tell, all foreigners were to languish in Ezekiel's underworldeven if some were ostensibly honoured while others are cast out to the farthest edges. By contrast, Ezekiel reports to the people of Judah that the LORD says: "I am going to open your graves, and bring you up from your graves, O my people; and I will bring you back to the land of Israel" (37:12) ${ }^{75}$

\section{G BIBLIOGRAPHY}

Astour, Michael C. "Ezekiel's Prophecy of Gog and the Cuthean Legend of NaramSin." Journal of Bible Literature 95/4 (1976): 567-579.

Baker, D. W. "Meshech (Person)." Page 711 in The Anchor Bible Dictionary. Volume 4. Edited by David N. Freedman; New York: Doubleday.

Bauckham, Richard J. Jude, 2 Peter. Word Bible Commentary 50. Dallas: Word, 1983. Bernat, David A. Sign of the Covenant: Circumcision in the Priestly Tradition. AIL 3. Atlanta: Society of Biblical Literature, 2009.

Block, Daniel I. The Book of Ezekiel: Chapters 25-48. Volume 2 of New International Commentary on the Old Testament 26. Grand Rapids: Eerdmans, 1998.

Boadt, Lawrence. Ezekiel's Oracles against Egypt: A Literary and Philological Study of Ezekiel 29-32. Biblica et Orientalia 37. Rome: Biblical Institute Press, 1980.

Bodi, Daniel. The Book of Ezekiel and the Poem of Erra. Göttingen: Vandenhoeck \& Ruprecht, 1991.

\footnotetext{
${ }^{75}$ See John T. Strong, "Egypt's Shameful Death and the House of Israel's Exodus from Sheol (Ezekiel 32.17-32 and 37.1-14)," JSOT 34 (2010): 475-504.
} 
Bowen, Nancy. Ezekiel. Nashville: Abingdon, 2010.

Cook, Stephen L. "Cosmos, Kabod, and Cherub: Ontological and Epistemological Hierarchy in Ezekiel." Pages 179-197 in Ezekiel's Hierarchical World: Wrestling with a Tiered Reality. Edited by Stephen L. Cook and Corrine L. Patton. Society of Biblical Literature Symposium Series 31. Atlanta: Society of Biblical Literature, 2004.

Cook, Stephen L., and Corrine L. Patton, eds. Ezekiel's Hierarchical World: Wrestling with a Tiered Reality. Society of Biblical Literature Symposium Series 31. Atlanta: Society of Biblical Literature, 2004.

Cook, Stephen L. and Corrine L. Patton. "Introduction: Hierarchical Thinking and Theology in Ezekiel's Book." Pages 1-23 in Ezekiel's Hierarchical World: Wrestling with a Tiered Reality. Edited by Stephen L. Cook and Corrine L. Patton. Society of Biblical Literature Symposium Series 31. Atlanta: Society of Biblical Literature, 2004.

Cornill, C. H. Das Buch des Propheten Ezechiel. Leipzig: Hinrichs, 1886.

Doak, Brian R. "Ezekiel's Topography of the (Un-)Heroic Dead in Ezekiel 32:17-32." Journal of Biblical Literature 132/3 (2013): 607-624.

Douglas, Mary. Leviticus as Literature. Oxford: Oxford University Press, 2000.

Ewald, Heinrich. Die Propheten des alten Bundes. Volume. 2. Stuttgart: Adolph Krabbe, 1841.

Fox, Michael V. "Sign of the Covenant: Circumcision in the Light of the Priestly 'ôt Etiologies." Revue Biblique 81/4 (1974): 557-596.

Garfinkel, Stephen Paul. "Studies in Akkadian Influences in the Book of Ezekiel." PhD dissertation: Columbia, 1983.

George, A. R. The Babylonian Gilgamesh Epic: Introduction, Critical Edition and Cuneiform Texts. Volume. 1. Oxford: Oxford University Press, 2003.

Greenberg, Moshe. Ezekiel 21-37: A New Translation with Introduction and Commentary. Volume. 2. New York: Doubleday, 1997.

Greenberg, Moshe. "The Design and Themes of Ezekiel's Program of Restoration." Interpretation: A Journal of Bible and Theology 38/2 (1984): 181-208.

Grünwaldt, Klaus. Exil und Identität: Beschneidung, Passa und Sabbat in der Priesterschrift. Bonner Biblische Beiträge 85. Frankfurt: Anton Hain, 1992.

Halévy, Joseph. Mélanges de critique et d'histoire relatifs aux peuples sémitiques. Paris: Maisonneuve, 1883.

Haran, Menahem. Temples and Temple-Service in Ancient Israel: An Inquiry into Biblical Cult Phenomena and the Historical Setting of the Priestly School. Second Reprint. Winona Lake: Eisenbrauns, 1995.

Hays, Christopher B. Death in the Iron Age II and in First Isaiah. Forschungen zum Alten Testament 79. Tübingen: Mohr Siebeck, 2011.

Himmelfarb, Martha. Tours of Hell: An Apocalyptic Form in Jewish and Christian Literature. Philadelphia: University of Pennsylvania, 1983.

Hitzig, Ferdinand. Der Prophet Ezechiel. Leipzig: Weidmann, 1847.

Hommel, Fritz. Grundriss der Geographie und Geschichte des alten Orients. München: C. H. Beck'sche, 1904.

Horowitz, Wayne. Mesopotamian Cosmic Geography. Mesopotamian Civilizations 8. Winona Lake, IN: Eisenbrauns, 1998.

Houston, Walter. Purity and Monotheism: Clean and Unclean Animals in Biblical Law. Sheffield: Journal of the Study of Old Testament Press, 1993. 
Hurvitz, Avi. A Linguistic Study of the Relationship between the Priestly Source and the Book of Ezekiel. Cahiers de la Revue biblique 20. Paris: Gabalda, 1982.

Jenson, Philip Peter. Graded Holiness: A Key to the Priestly Conception of the World. Journal of the Study of Old Testament Supplement Series 106. Sheffield: JSOT Press, 1992.

Kasher, Rimon. "Anthropomorphism, Holiness and Cult: A New Look at Ezekiel 4048." Zeitschrift für die Alttestamentliche Wissenschaft 110/2 (1998): 192-208.

Katz, Dina. The Image of the Netherworld in the Sumerian Sources. Bethesda: CDL Press, 2003.

Knohl, Israel. The Sanctuary of Silence: The Priestly Torah and the Holiness School. Winona Lake: Eisenbrauns, 2007.

Koch, Klaus. "Die Eigenart Der Priesterschriftlichen Sinaigesetzgebung." Zeitschrift für Theologie und Kirche 55/1 (1958): 36-51.

Konkel, Michael. "The System of Holiness in Ezekiel's Vision of the New Temple (Ezek 40-48)." Pages 429-455 in Purity and the Forming of Religious Traditions in the Ancient Mediterranean World and Ancient Judaism. Edited by Christophe Nihan and Christian Frevel. Dynamics in the History of Religions 3. Leiden: Brill, 2012 .

Kutsko, John F. Between Heaven and Earth: Divine Presence and Absence in the Book of Ezekiel. Winona Lake: Eisenbrauns, 2000.

Lapinkivi, Pirjo. The Neo-Assyrian Myth of Ištar's Descent and Resurrection. Helsinki: Neo-Assyrian Text Corpus Project, 2010.

Launderville, Dale. Spirit and Reason: The Embodied Character of Ezekiel's Symbolic Thinking. Waco: Baylor University Press, 2007.

Lilly, Ingrid E. Two Books of Ezekiel: Papyrus 967 and the Masoretic Text as Variant Literary Editions. Vetus Testamentum Supplements 150. Leiden: Brill, 2012.

Livingstone, Alasdair. "The Underworld Vision of an Assyrian Prince." Pages 68-76 in Court Poetry and Literary Miscellanea. State Archives of Assyria 3. Helsinki: Helsinki University Press, 1989.

Lyons, Michael A. From Law to Prophecy: Ezekiel's Use of the Holiness Code. LHBOTS. New York: T\&T Clark, 2009.

Marzouk, Safwat. Egypt as a Monster in the Book of Ezekiel. Tübingen: Mohr Siebeck, 2015.

Mein, Andrew. Ezekiel and the Ethics of Exile. Oxford: Oxford University Press, 2006.

Milgrom, Jacob. Leviticus 1-16: A New Translation with Introduction and Commentary. Anchor Bible 3. New York: Doubleday, 1998.

- Leviticus 17-22: A New Translation with Introduction and Commentary. Anchor Bible 3A. New York: Doubleday, 2000.

- "The Graduated Hattāàt of Leviticus 5:1-13." Journal of the American Oriental Studies 103/1 (1983): 249-54.

Mimouni, Simon C. La circoncision dans le monde judéen aux époques grecque et romaine: Histoire d'un conflit interne au judaïsme. Colorado Real Estate Journal. Paris: Peeters, 2007.

Niditch, Susan. "Ezekiel 40-48 in a Visionary Context." Catholic Biblical Quarterly 48/2 (1986): 208-224.

Olyan, Saul M. Rites and Rank: Hierarchy in Biblical Representations of Cult. Princeton: Princeton University Press, 2000. 
Wells \& Hays, "Degradation,” OTE 33/3 (2020): 490-514 513

Petersen, David L. "Creation and Hierarchy in Ezekiel: Methodological Perspectives and Theological Prospects." Pages 176-177 in Ezekiel's Hierarchical World: Wrestling with a Tiered Reality. Edited by Stephen L. Cook and Corrine L. Patton. Society of Biblical Literature Symposium Series 31. Atlanta: Society of Biblical Literature, 2004.

Potts, D. T. Archaeology of Elam: Formation and Transformation of an Ancient Iranian State. Cambridge: Cambridge University Press, 2015.

Premstaller, Volkmar. Fremdvölkersprüche des Ezechielbuches. Forschung zur Bibel 104. Würzburg: Echter, 2005.

Propp, William H. "Circumcision: The Private Sign of the Covenant." Biblical Research 20.4 (2004): 22-29.

Sanders, Seth L. "The First Tour of Hell: From Neo-Assyrian Propaganda to Early Jewish Revelation." Journal of Ancient Near Eastern Religion 11 (2009): 151169.

Sarna, Nahum M. Exodus. The JPS Torah Commentary. Philadelphia: The Jewish Publication Society, 1991.

Smith, Jonathan Z. To Take Place: Toward Theory in Ritual. Chicago: University of Chicago Press, 1992.

Stevenson, Kalinda Rose. Vision of Transformation: The Territorial Rhetoric of Ezekiel 40-48. Society of Biblical Literature Dissertation Series 154. Atlanta: Scholars Press, 1996.

Streck, Maximilian. Assurbanipal und die letzten Assyrischen Könige bis zum Untergange Ninivehs. 1916. Reprinted in Leipzig: Zentralantiquariat, 1975.

Strong, John T. "Egypt's Shameful Death and the House of Israel's Exodus from Sheol (Ezekiel 32.17-32 and 37.1-14)." Journal for the Study of Old Testament 34/4 (2010): 475-504.

Suriano, Matthew. A History of Death in the Hebrew Bible. Oxford: OUP, 2018.

Tallqvist, Knut. Sumerisch-akkadische Namen der Totenwelt. STOr 5/4. Helsinki: Societas Orientalis Fennica, 1934.

Tawil, Hayim. Akkadian Lexical Companion for Biblical Hebrew. New Jersey: Ktav, 2009.

Vanderhooft, D. S. "Ezekiel in and on Babylon." Pages 99-119 in Bible et ProcheOrient, Mélanges André Lemaire III. Transeuphratène 46. Paris: Gabalda, 2014.

Von Soden, Wolfram. "Die Unterweltsvision eines assyrischen Kronprinzen." ZA 43 (1936): 1-31.

Wellhausen, Julius. Prolegomena to the History of Israel: With a Reprint of the Article Israel from the Encyclopaedia Britannica. Translated by J. S. Black and A. Menzies. Edinburgh: Black, 1885. Repr. Eugene, OR: Wipf and Stock, 2003.

Wright, David P. The Disposal of Impurity: Elimination Rites in the Bible and in Hittite and Mesopotamian Literature. Society of Biblical Literature Dissertation Series 101. Atlanta: Scholars Press, 1987.

Yee, Gale A. "The Anatomy of Biblical Parody: The Dirge Form in 2 Samuel 1 and Isaiah 14." Catholic Biblical Quarterly 50/4 (1988): 565-586.

Zimmerli, Walther. Ezekiel 2: A Commentary on the Book of the Prophet Ezekiel Chapters 25-48. Edited by Paul D. Hanson. Translated by James D. Martin. Volume 2 of Hermeneia. Philadelphia: Fortress, 1983. 
514 Wells \& Hays, "Degradation," OTE 33/3 (2020): 490-514

Sara Wells, Fuller Theological Seminary. Email: sarawells@fuller.edu. ORCID: https://orcid.org/0000-0002-0420-3230.

Christopher B. Hays, Fuller Theological Seminary. Email: hays@fuller.edu. ORCID ID: https://orcid.org/0000-0003-1694-75099. 